\title{
The Politics And Political Implications Of Oil And Gas Exploration In Africa: An Analysis Of American Oil Corporations In Nigeria
}

Michael Adams, Texas Southern University, USA

Gbolahan Osho, Prairie View A\&M University, USA

Quonna Coleman, Texas Southern University, USA

\begin{abstract}
This study will identify the extent in which American oil companies make billions daily from oil production, while local Nigerians suffer daily from poverty. The focus of this research will be on the population of Niger Delta, Shell Oil Company and the Nigerian government. I will define and establish an illustration of the poverty-structured environment that surrounds Niger Delta and the revenue success of Shell Oil Company and Nigeria's government. This research will open the eyes of American oil companies, Nigeria's federal government and people around the world to the revenue that is coming into Nigeria, but the communities are still living in poverty. Something needs to be done; if something is not done, some the people of Niger Delta will continue to retaliate.
\end{abstract}

\section{INTRODUCTION}

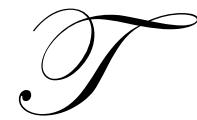

he purpose of this study is to examine the reaction of local Nigerians as American oil companies profit from their oil resources and they receive nothing in return. By conducting a research study of this magnitude, American oil companies will be awakening to the effect of their involvement in the Nigerian oil industry on local citizens. This study will provide awareness to corporations of why Nigerians are retaliating against them. Corporations will also be conscious of how their involvement in the Nigerian oil industry effects the environment and the living conditions of local citizens. The study will illustrate that the American oil companies' dependence on Nigeria's oil resources will not only continue to affect the present generation, but will have a lasting affect on generations to come. The outcome of this study will create beneficial results that will encourage American oil companies to formulate an ethical practice of contributing to Nigeria's living and environmental issues and eventually, at some point contribute to the ending of continuous destruction of the lives and environment of Nigeria without compensation. The American oil companies focused upon will be Royal Dutch Shell and the research conducted will be based on the production and operations conducted by Shell Companies located in Nigeria.

Nigeria, Africa's largest oil producer, on an average day can pump 2.5 million barrels of oil, which accounts for 3\% of global consumption. An article recently published in the Wall Street Journal states, "Most of its (Nigeria) output is exported, making it the fifth-largest foreign supplier of crude to the U.S., behind Canada, Mexico, Saudi Arabia and Venezuela" (The Wall Street Journal, A6). Despite the richness of natural oil resources in Nigeria, the country is ranked the $20^{\text {th }}$ poorest country. Much of the country's poverty and underdevelopment can be contributed to the misguidance in governance, mismanagement of resources, various political issues and lack of infrastructures. American oil companies are utilizing Nigeria's crude oil resources to gain profit, in addition to the utilization of the Nigerian environment to produce and operate within the oil industry. The Niger Delta region is 
currently involved in the most conflict surrounding oil companies taking their resources and not giving anything back in return.

In January 1956, Shell became the first American oil companies to begin drilling in Nigeria's oil rich land. "Royal Dutch Shell is one of the most profitable companies in the world. A substantial part of this profit comes from the plum oil concessions it has generated in the Niger-Delta" (Douglas and Okonta, 2) and Shell Oil Company operates as a joint venture with the local Nigerian Government, TotalFinaElf, and Agip (Azienda Generale Italiana Petroli) producing $40 \%$ of Nigeria's crude oil. Shell operates four companies in Nigeria: Shell Petroleum Development Company (SPDC - the first and largest oil and gas company in Nigeria), Shell Nigeria Exploration and Production Company (SNEPCO), Shell Nigeria Gas (SNG), and Shell Nigeria Oil Products (SNOP). In addition to the four companies, Shell has major stake in Nigeria Liquified Natural Gas (NLNG), which operates under a joint venture agreement and as the technical advisor.

Nigeria's governmental return is 55\% from Shell Oil Company only, so just imagine the total revenue the government receives from all American oil companies (i.e. Exxon, TEXACO and etc.) Government's investment in the American oil industry is approximately 95\%, which means the government gets most of the revenue created from the production of crude oil. Nigerian National Oil Corporation serves as the operator for Nigeria's joint ventures with American oil companies, through this venture the Nigerian government conducts petroleum exploration and development. The government's investment in the oil investment is done on a large scale, but the people are not reaping the benefit. The reaction of many Nigerians to the oil industry derives from the selfishness of their government.

Many groups in the Niger-Delta area desire compensation for the resources the Nigerian government and oil companies are profiting from. "Shell, in collaboration with successive governments in Nigeria, has been extracting billions of dollars worth of oil and gas from Nembe and other communities in Niger Delta since 1956 without giving much in return" (Douglas \& Okonta, 1-2). In response to the actions of the Nigerian government and oil companies, groups are utilizing attacks and violent threats as tactics to get payouts, job programs, or even funding for better school programs. The infliction imposed upon Niger Delta locals has caused disruption within their communities. The following article asserts, "But territorial disputes between rival gangs and access to crudesmuggling routes in the Delta also have triggered bloodshed" (The Wall Street Journal, A6). The lack of response from officials and oil companies has and continues to be an unresolved subject. For 40 years, Shell has despoiled Nigeria's environment and exploited their resources without offering any form of compensation. Nigerians are fed up with the actions of their government and oil companies and they insist on having reparations.

\section{RESEARCH DESIGN}

The oil industry is booming in Nigeria and the revenue of American oil companies is soaring, but Nigerian locals are suffering daily from poverty, endangered environment and the desire for compensation. As the one of the largest oil exporters, Nigeria has been and continues to be a great source of revenue for American oil companies and the Nigerian government. Unfortunately, the revenue of the oil industry has not contributed to the heightened issues of poverty, environmental degradation, sickness and unemployment; just to name a few. The utilization of Nigeria's oil resources plays an important role in how Nigerian locals formulate their negative and positive opinions of American oil companies and the Nigerian Government. I will be conducting a content analysis on the reaction of local Nigerian communities in regard to the influx of American oil companies utilizing their crude oil resources. Along with the content analysis, I will conduct an experimental analysis, which will determine whether the reaction of local Nigerian communities to American oil companies crude oil utilization has affected the production and operation of American oil companies in Nigeria.

\section{HYPOTHESIZES:}

Content Analysis Hypothesis: Locate individuals living in Nigeria feel Royal Dutch Shell is taking their crude oil resources, but not putting anything back in return. 
Experimental Hypothesis: The utilization of Nigeria's oil resources has cause the reaction of Nigerian communities to the affect the production and operation of Royal Dutch Shell.

$\mathbf{H}_{1}$ : The reaction of the Niger Delta community will impacted the production or operation of Royal Dutch Shell.

$\mathbf{H}_{\mathbf{0}}$ : The reaction of the Niger Delta community has not had an impact on the production or operation of Royal Dutch Shell.

Theses hypothesizes will exhibit how utilization of a country's resources with no return, affects the reaction of citizens within the country and the production and operation of the corporation. Statistical information derived from these hypotheses should encourage corporations to offer some type of return to the communities in which resources are widely utilized.

Through the collection of data, I will show just how much the American oil companies, Shell in particular invest in Nigeria's crude oil resources and the influx of revenue received from production and operation. The data will also establish an understanding of the reaction of Nigerian locals as companies continue to utilize their resources with no return. The content analysis research, statistical analysis, and a review of literature will be the basic research design for this study. The focus of this research will be on the population of Niger Delta, Shell Oil Company and the Nigerian government. I will define and establish an illustration of the poverty-structured environment that surrounds Niger Delta and the revenue success of Shell Oil Company and Nigeria's government.

The illustration will be established by measuring the concepts of these three questions:

1. How has Shell's utilization of Nigeria's oil resources affected the conditions, in which Niger Delta citizens live (i.e. poverty, eenvironmental degradation, desire for compensation and etc.)?

2. Did the reaction of Nigerian locals affect the production and operation of Shell Oil Company?

3. Has the government played a role in eliminating the utilization of oil resources with no return to the locals, and has it responded to the reaction of local Nigerian citizens?

The answer to these questions will operate as an index for the issues challenging the survivor of Niger Delta locals and the actions required of Shell Oil Company and Nigeria's government.

\section{LITERATURE REVIEW}

There have been a number of studies conducted by journalists, novelists, essayists, and historians on the impact of oil production on Nigerian locals. The authors analyzed have collectively concluded that both the Nigerian government and oil companies have recognized the issues Nigerian communities are faced with, but nothing has or is being done about it. Instead of oil companies giving local Nigerians portions of their earnings to prevent retaliation, they are holding off on production in areas that are considered to be dangerous. Each author offers a descriptive image of how the oil industry has restructured Nigeria. Authors enlightened readers on the corruptness, inhumanness and disruptive actions American oil companies have imposed upon Nigerian locals.

Augustine A. Ikein studied the impact of the oil industry on the developing country of Nigeria. His study revealed that the mere existence of a profitable oil industry in Nigeria would not create balance for the developing area. For development to take place, Ikein suggested that the Nigerian government and oil companies reduce oil production in areas that they have damaged and outline a development plan for communities in Nigeria. Ikein's suggestions illustrate his focus on the relationship between Nigeria's oil industry, the national and regional areas, and its impact on the environment. All of the topics focused on by the author contribute to my understanding of the effect the oil industry can have on a country, such as Nigeria, as they attempt to development their culture, environment, and lives. Ikein's work provides a historical setting for Nigeria's development as a country and the development of the oil industry within the country. The information offered by the author is essential to understanding Nigeria's development and destruction. The author offers the solution of government and oil company intervention to address the problems created by the oil industry in Nigeria, but the solution in which he 
offers does not hold merit. Greed usually outweighs moral judgment, and if the government and oil companies are both successfully profiting from oil production, it is not likely that they will reduce production. Ikein provides resourceful information but does not address the presented hypothesis directly.

The findings of author Anthony Sampson, writer of The Seven Sisters: the Great Oil Companies and the World They Made presents detailed information on the seven dominant oil companies in the petroleum world. The author does not offer very much detail about the country of Nigeria; his focus is mainly on Libya. Nigeria is mentioned only as a comparison for oil production in thier country vs. Libya. The author reveals that many prefer Libyan oil to Nigerian oil because it is cheaper and closer to export. Sampson writes of the history of the seven oil companies and their role in the development of the oil industry. He offers comprehensive information about the history of Royal Dutch Shell, but it does not provide a linkage between the company and Nigeria. I would recommend this book to any individual that is interested in the appealing side of the oil business. The weakness of Sampson's work is that it vaguely provides an illustration or description of the corruptness in the oil business.

Emmanuel Nnadozie focused his study on Egbema, which is a River State in Nigeria. His study acknowledged that Egbema has and continues to endure the same affects of oil production as Niger Delta. Egbema communities were neglected as the oil industry began to boom in their area. "Their opinion is that the discovery of oil is a curse that means only poverty, hunger, disease, suffering, deprivation, and exploration" (Nnadozie, 75). The book is actually a good source because it includes illustrates of graphs and charts that depict the damage oil companies have done in Egbema, but the information is not current data. The data presented in the book provides historical information regarding the oil industry in Egbema, dating back from 1979 to 1992. Had the information been current it would have effectively concluded statistically the current impact oil companies have on Nigeria. The author offered detailed information regarding the impact of oil companies, which he refers to as a disease. Nnadozie offers a solution similar to that offered by Ikein five years earlier; he recommends that the restructuring of the Nigerian government systems will address the issues of Egbema, Nigeria. The restructuring of the Nigerian government is currently a hot button issues in Nigeria. According to a recent article in The Wall Street Journal, "The ballot could produce Nigeria's first civilian-to-civilian change government. If things go wrong, it could disrupt the country's significant oil production" (Cummins, A6). If change does occur and new officials can be appointed, they must have a structured plan of how they will address the issues of poverty, hunger, environmental degradations, lack of jobs and improper education facilities. I pose the following questions: Will the new government be prepared or able to handle the magnitude of problems Nigeria is faced with? Candidates must be aware of the problems in which they will have to cleanup. Restructuring of the government is the current solution, but what happens if this government turns out to be corrupt too.

In the story Where Vultures Feast: Shell, Human Rights, and Oil in the Niger Delta, authors Oronto Douglas and Ike Okonta express their encounters with one of the most powerful multinational oil companies in the world. The oil company focused on by the authors is the all-famous Royal Dutch Shell. I find this source to be a vital resource for the research conducted. It focuses on Royal Dutch Shell and Niger Delta, which is the company and area of interest for this research. The authors of the book document the impact Shell has had on Niger Delta, the pollution, the lack of response from the company, and the inhumane and corrupt activities of the company. Their findings reveal that Shell shrouds the financial side of its operations in Nigeria in mystery, using an elaborate cover of misleading statistics, vague statements, and sometimes-outright hostility to ward off prying eyes. In my opinion if one has nothing to hide, they would truthfully provide statistically information and comments regarding their involvement in Niger Delta. This book provides an insightful history of how Shell has disrupted and destroyed the lives and environment of Niger Delta locals. Communities lack essential resources that are widely used daily here in the United States electricity for example, pipe-borne water, hospitals, proper housing, and motorable roads. The Ogoni group with Niger Delta has cried out multiple times to Shell for help within their communities and all of their efforts have been ignored. "The Ogoni recognized the insidious impact of Shell's oil exploration and production activities on their environment from the onset. Letters written by Ogoni community leaders in April 1970, when the company was still a joint venture between Shell and British Petroleum described how the multinational's activities were seriously threatening the well-being and even the very lives of the Ogoni. In yet another letter two months later, representatives of Dere Students Association complained to Shell officials about the constant gas flaring and noise generated by the company's operating in the community. They also criticized the practice of laying 
oil pipelines over community farmlands and asked Shell to remedy the situation. All these protest, were ignored" (Douglas and Okonta, 75-76).

The strength of the authors' study was illustrated in several case studies published in their book. Each case provided an analysis of Shell's impact on various Nigeria communities. The cases expressed the frustration and nonviolent attempts of communities to inform Shell of the damage its oil production was causing in the lives and environment of Nigerian locals. As highlighted in the complaints of the Ogoni community Shell's responses to the needs of the communities have not been address and creates an unstable company structure. According to the study of the authors, Shell has and continues to disregard the rules and regulations implemented by the Nigerian oil industry. The understanding and image I have of Shell as an organization has been revolutionized by the study presented by Douglas and Okonta. The company has not lived up to its "Enterprise First" behavior core values of honesty, integrity, and respect for people. The authors exposed Shell's dirty laundry and the profound infliction it has positioned upon Niger Delta and other areas in Nigeria. Authors enlighten readers on the bloodshed caused by Shell to protect their oil investment. The following two questions are utilized as a bases for the study conducted by Douglas and Okonta, "How do we heal the wound that Shell has inflicted and continues to inflict on Niger Delta, one of the most endangered human ecosystems in the world?" "What must the international community, the people of Niger Delta, and Nigerians at large do to stop this juggernaut from further damaging the area, threatening a people and their way of life?" (Douglas and Okonta, 3).

Despite the resourceful information provided by this book, the authors do not offer solutions to the questions in which they posed. They basically express that Shell unofficially acts as the senior partner for Nigeria's oil industry and they have the Nigerian government under their control. Douglas and Okonta oppose the suggested solutions offered by Ikein and Nnadozie, but they don't offer a resolution. They feel that there is nothing the government can do against Shell in regards to the problems within the Niger Delta. Ultimately it is up to the people of the Niger Delta to protect their most valuable heritage and their environment from further blight (Douglas and Okonta, 204). This has been and is currently the approach the people of the Niger Delta are taking, but their efforts have been useless. Their attempts have not provided concession, but they did manage to stop some of Shell production. Where Vulture Feast: Shell, Human Rights, and Oil in the Niger Delta has been the most functional supply of information for the entire research. It was well written and addressed the hypothesis directly. Douglas and Okonta established an understanding of the greed of the Royal Dutch Shell Oil Company and its affect on the oil rich land of the Niger Delta.

\section{STATISTICAL ANALYSIS}

For almost 50 years, Shell has operated and produced oil in Nigeria's oil rich land of the Niger Delta. The communities in Niger Delta have seen little or no support from Shell Oil Company. Statistics have been complied to express the impact Shell has had and continues to have in the country of Nigeria. The following analysis will include statistical data collected regarding the governmental involvement in the oil industry, oil production and exporting, and the environmental and living conditions of communities in the Niger Delta. Since Shell's entry in 1956 as the first commercial oil field the company had operated in a profitable joint venture with Nigerian National Petroleum Corporation (NNPC), TotalFinaElf, and Agip.

Shell Petroleum Development Company of Nigeria Ltd. (SPDC) is the largest operator of Nigeria's oil and gas joint venture. The federal government of Nigeria regulates and participates in the oil industry in its state oil corporation, Nigerian National Petroleum Company, which dominates the joint venture operation by 55\%. Shell gains 30\%, TotalFinaElf 10\%, and Agip 5\% from their joint venture involvement with Shell Petroleum Development Company of Nigeria Ltd. The government of Nigeria is the most profitable from the joint venture connection; for years the government has not properly used the revenue gained from the oil industry. 


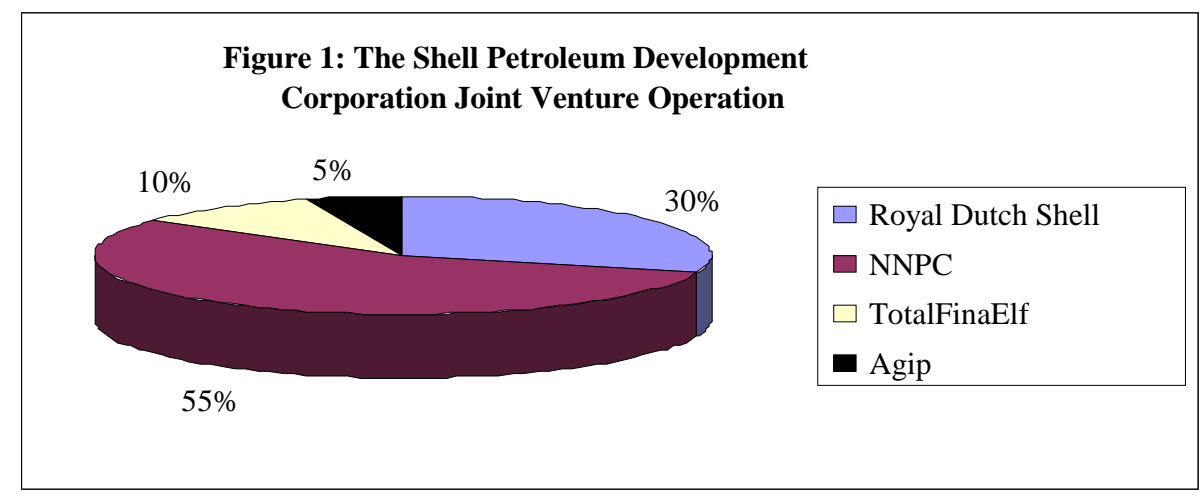

Nigeria's government is not concerned with needs of the communities in the Niger Delta; they are currently the most profitable organization within the joint venture. Writer Michael Watts refers to the controls of the Nigerian oil industry the "oil mafia" which includes oil companies and their federal government. "At present prices, the oil mafia controls a black economy worth billions of dollars annually" (Watts, 3) The majority of Nigeria's oil production is done along the Niger Delta, once Nigeria's major producer of palm oil, now house the Shell major oil production and operation.

Figure 2: Monthly Crude Oil Production for 2005

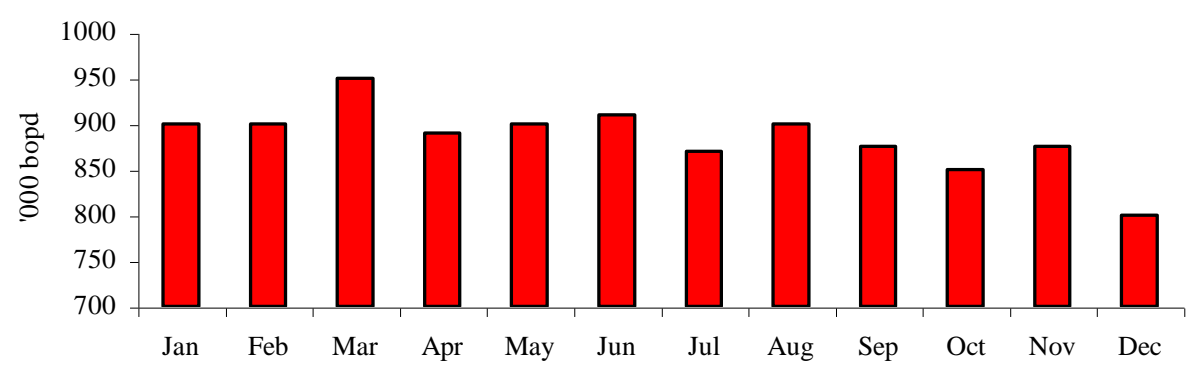

As shown in Figure 2, Shell's oil production and operation was at its peak in the month of March, but it was at its lowest in December. The goal of the Nigerian government is to increase the oil and gas production to 4 million barrels of oil per day by 2010 . They are striving to accomplish their goal, which will lead to an increase in revenue for the government. The high level oil and gas production expected will progressively damage the environment and living conditions of the communities living in the Niger Delta. The cause of much of the damage that has occurred in the Niger Delta is the result of oil spills. "Shell Petroleum Development Company of Nigeria (SPDC) is losing 187,000 barrels per day due to a major oil spill at its Nembe Creek Trunk Line. The company also had to shut down ten flow stations as a result of the major spill which occurred penultimate Sunday" (Ayankola, 1). The spills have not only affected Niger Delta, but they have halted the operation and production of oil and gas for the company. Oils spills have produced waste pollution, soil degradation and climate changes, all of which have troubled the living environment of Niger Delta locals. 


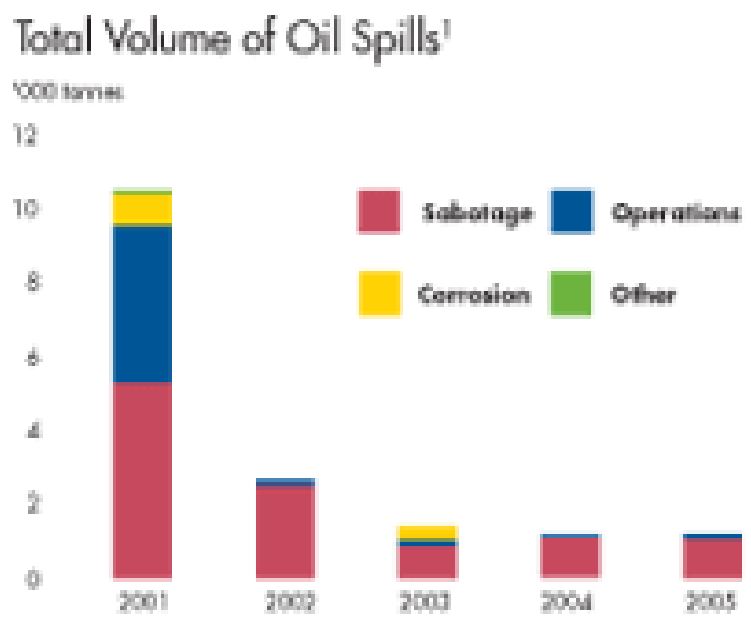

\section{Total Number of Oil Spills}

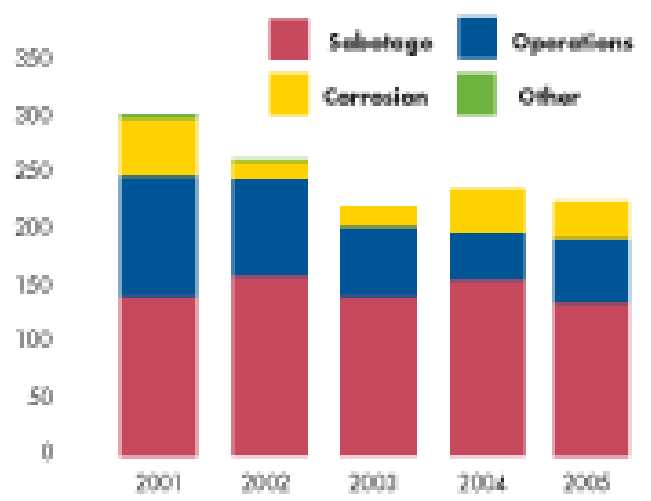

Source: Shell in Nigeria: Shell Nigeria Annual Report 2005

Most, if not all, of the spills that occurred between 2001-2005 were controllable incidents. Corrosion and equipment failure were the top causes for major oil spills and there was an estimated increase in total volume of oil spoils in 2005. Spill results have decreased, but the spills continue. The results ascertain a numerical view of the impact Shell has on Nigeria and the main organization that is the most profitable. It is unfortunate to know that the Nigerian government profits vastly from the oil and gas industry and the communities have nothing to show for it.

\section{RESULTS AND FINDINGS}

Unemployment is due to the lack of opportunities provided to Nigerian locals from the government. Most if not all of the employees of the oil companies are from other countries around the world (i.e. America, China, 
Honduras and etc.). The Nigerian economy is achieving vastly, but unemployment rapidly grows among young people who graduate from the country's tertiary institutions. Unemployment has resulted in the theft of oil products, scams involving the Shell Nigeria Company name, and, the increase in violence. Nigerian communities are seeking compensation for the utilization of their resources. American oil corporations along with the Nigerian Government are profiting tremendously from the crude oil production. Local Nigerians should not be subject to a world of poverty when their country is one of the richest oil exporting countries. The Nigerian government receives 95\% return on crude oil investments, but local communities are getting nothing in return. As a reaction to the lack of return from the government, local individuals have began taking their arguement out of the oil companies (i.e. kidnappings, ransom calls, and etc.).

Rising security issues force Shell to place many operations in Nigeria on hold. Within weeks of each other four flow stations were occupied and hostages were taken. This resulted in the postponement of operations. Shell plans to resume operations once the environment is safe. Shell's future in Nigeria involves the investment of 12 inter-related oil and gas projects - seven onshore oil and gas gathering, three offshore projects, an offshore pipeline, and a project to expand the liquefied natural gas plant. The goal of Shell is to stay around for the long haul. The company has the desire to focus on the stakeholders of their Nigerian company and invest in their interests. The company's focus is on the acceptance in the "minds and hearts" of their stakeholders.

With little or no effort, the government has not addressed the rising security issues predominately in the Delta Niger. Weekly kidnappings and killings of oil industry workers are being reported. The tactics being used by the government to address the violence issues have been unsuccessful and have resulted into the killing of hostages. The retaliation taken upon the oil workers by the local Nigerian communities is a result of the lack of resources provided to them by the government. The revenue of the government and the influx of people living in poverty are soaring simultaneously. "Is the government concerned about the views of the Nigerian people" is an issue that concerns many local Nigerians. An article in the Nigerian Tribune reads, "...it is particularly worrisome that our recurring calls on the government at various levels and their agencies to discuss and resolve the myriad of problems facing the region has fallen on deaf ears" (Ahiuma-Young, 3). The Nigerian government has not addressed the kidnapping problems and the people of Nigeria feel something should be done. It is my opinion that the government does not want address to the various issues surrounding the violence directed toward the oil industries because they also have their investment at stake.

\section{CONCLUSION}

In conclusion, this study has proven the researched hypothesis to be true. Royal Dutch Shell has operated and produced in Nigeria for almost 50 years and no concession has been distributed to the locals of Nigeria, in particular the Niger Delta. As a result of the impact Shell and other oil companies have had on Nigeria, the citizens have formulated a negative opinion of American oil companies. In regard to their negative opinion, they have been and continue to be, violent toward those involved with the oil industry of Nigeria, including their own government. Violence has been the tactic used as local Nigerians desire for concession increases. Due to the increases in violence, Shell has closed many of its operations in the Delta earlier this year. CEO of Shell, Jeroen van de Veer, expressed that it is likely the Shell operations will remain closed unless the Nigerian elections take place and violence dies down. The Nigerians are fed up with the harsh treatment of oil companies and its government. Additionally, in response to the lack of support received the Niger Delta communities have formed activist groups, which set out to express their concerns about the impact of Shell and other oil companies within their country. Findings have concluded that the impact Shell has had on Nigeria has caused communities to suffer from poverty, and unemployment, and are environmentally dangerous. The government has not effectively contributed to the safety and well-being of its citizens. The research has established the understanding that the government is one of the major profiteers of the oil industry. Nigeria should not be in the condition in which it is. Although it is considered to be an underdeveloped country, the financial resources should be allocated differently. Now that the election period is completed and Nigeria has installed its first civilian-to-civilian government, it is the hope of the people that things will change. 
The solution in which I offer to address the issues of Nigeria and its oil-rich land is for the Niger Delta communities to continue to fight against the infliction placed upon them by the oil companies and their government. The community's nonviolent acts of writing letters of concern and protesting received no response; it wasn't until the violence beyond those things began to change. The violence has halted operations and caused both the Nigerian government and Shell to lose profits. Since the government is no help and Shell for years has not compromised, it seems to me that violence is currently the only answer. The only downfall from that solution is if the operation and production of oil companies stop the country will have absolutely no incoming revenue. The second solution in which I offer is for the government to distribute its finance among the communities within Nigeria. With continuous effects from activist groups the government should realize that their current practice of holding all oil revenue is an unfair and cruel practice. I encourage both Shell and the Nigerian government to reevaluate their current oil industry practices. Development is needed within the Nigerian communities, and as the fifth largest export of oil the country should be developed.

\section{REFERENCE}

1. Ahiuma-Young, Victor. "Govt absence speaks volume-Oil Workers.” The Vanguard. 28 December 2006. <www.vangrardngr.com/articles/2002/features/labour>.

2. $\quad$ Ayankola, Martin. "Shell loses 187,000 bpd to fresh oil spill." Nigerian Tribune. 13 March 2007. <http://www.tribune.com.ng/13032007/news/news2.html.

3. Cummins, Chip. "Nigeria's Election Heightens Oil Worries: Violence, Legal Battles Unsettled Crude Exporter, U.S. Is Watching Closely." The Wall Street Journal. 11 April 2007: A6.

4. Douglas, Oronto and Ike Okonta. 2003. Where Vultures Feast: Shell, Human Rights, and Oil in the Niger Delta. San Francisco: Sierra Club Books.

5. Ikein, Augustine A. 1990. The Impact of Oil on a Developing Country: The Case of Nigeria. New York: Praeger Publishers."Making gas work for Nigeria through legislation.” The Guardian. 26 January 2007 <www.odili.net/news/source/2007/jan/26/76.html >.

6. Nnadozie, Emmanuel U. 1995. Oil and Socioeconomic Crisis in Nigeria: A Regional Perspective to the Nigerian Disease and The Rural Sector. New York: Mellen University Press.

7. $\quad$ Rasheed, Komolafe. "Oil exploration in Nigeria: The x-ray." Nigeria Tribune. 09 June 2006. <www.tribune.com.ng/06092006/eog.html>.

8. Rasheed, Komolafe. "Pengassan condemns killing of colleagues in Niger Delta." Nigeria Tribune. 14 December 2006. 〈www.tribune.com.ng/14122006/eog.html〉.

9. $\quad$ Rothermund, Heinez. "The role of international industry in Nigeria."27 April 2000. $\langle$ www.shell.com/nigeria>.

10. Sampson, Anthony. 1991. The Seven Sisters: The Great Oil Companies and the World They Made. New York: The Viking Press Inc. "Shell in Nigeria." 27 November 2006 <sww.shell.com/home/news/Highlight/1543769682/Article.aspz>

11. Watts, Michael. “Crisis in Nigeria: Oil Inferno." CounterPunch:American's Best Political Newsletter. 2 January 2007. 
NOTES 